\title{
Exploring Old and New Paths in Theodicy
}

\author{
Bethany Sollereder
}

Ten years after its release, re-reading Christopher Southgate's The Groaning of Creation fills me with the same admiration it did initially. The scope of the work is broad, the scholarship is powerful, and the tone is poetic. Continued reflection on the book over the last decade has led to a series considerations, primarily about eschatological questions, that will fill the first half of this essay. The second half of this essay will explore new paths in theodicy, drawing out how Southgate's approach has led to the emergence of what I have called "compassionate theodicy".

The Problem of Particularity: Why Didn't God Make Heaven first?

One of many neglected questions Southgate faces head-on in his work is "Why did God not just create heaven?" He writes: "why, if an altered physics makes possible an altered and pain-free cosmos, did God not create this in the first place?" (Southgate 2008, 90). To this, Southgate raises his "Only way" argument: as far as anyone knows, a process of evolution is the only available means by which to allow complex "creaturely selves" to develop without constant divine intervention. Heaven may be a perfect resting place for selves, but it cannot be the place that generates them.

However, I wonder if there is another possibility for how one might articulate the "only way" argument without claiming that this universe was the best way to create creaturely selves. I suggest instead that one could point to the contingency of historical development and the complexity of identity to develop an alternative "only way" argument. My approach begins with the thought that, apart from humans existing, it might not be possible to imagine them in all their complexity. 
Humans are a result of evolutionary modification after modification. Out of the unlimited physical possibilities for physical creatures, how would God have lighted upon a five-fingered mammal with an appendix and a poorly adapted spinal column if creation was performed de novo? Darwin once described the odd outcomes one would have to attribute to design if God were to make us the creatures we are: “man's rudimentary mammæ; bladder drained as if he went on all four legs; \& pug-nose." (Darwin 1861) There is nothing biologically obvious about humans. Yet, how much could be removed or changed before you no longer have a human? I do not plan to try to solve that old philosophical conundrum, but only wish to suggest that humans are inseparable from the history that has shaped all the specifics of their DNA, their instincts, and their desires.

A critic of Southgate's only way argument, Mats Wahlberg, argues that Southgate's view is "vulnerable to the doppelgänger-objection... Suppose that God would createdirectly — an exact molecular duplicate of a certain, individual pelican... [it is] not a product of evolution, so a process of evolution cannot be the only way for God to create creaturely selves" $(2014,46)$. But where did God get the molecular map of that pelican, except from evolution? And apart from evolution, what are the chances of God deciding to create the pelican that evolution produced and not the myriad of possibilities of pelican-like beings?

A critic like Wahlberg might reply that God could have run a mental simulation of earth history that would have resulted in the human (or pelican) form and then created from that template. You would have humans without eons of animal suffering. I see two problems here. First, such an approach is inappropriately anthropocentric. It is not just humans that God is interested in, but all the numberless creatures that have populated the universe. Creating the final forms of all the other creatures that inhabit the world would end up looking just like playing out history as it actually happened. Second, a divine mental simulation would either have decision points (where God determined particular outcomes of 
underdetermined circumstances) or else God would have to run a simulation of all possible outcomes of uncertain events. If the former, then there is the question of how God made one choice instead of another and (in the case of simulating the choices of free agents) whether free choices can be predicted. If God ran a simulation of all possible outcomes, then God would end up in the initial conundrum of trying to choose one outcome as the outcome to actually create amongst the innumerable choices. How does God choose the possibility that led to the pelican amongst the alternative choices? ${ }^{1}$ It may be that there is only one way to come up with both pelicans and people, and that is the evolutionary process.

The contingency and ever-shifting populations of evolution raise another question about how Southgate defines the work of God in creation. There is a strain of Platonic realism in Southgate's work that seems at odds with the dynamism of evolution. When he describes the work of the Spirit and the Logos, Southgate writes:

The logos of a thing is its nature and what God intends it to be... biological organisms and species are best seen as representing points and peaks within evolutionary fitness landscapes... The Logos is being understood to confer pattern and common significance to the organism as a member of a species (2008, 61-62).

Southgate is quite careful to maintain a dynamic sense, to say that each fitness peak is a "possibility imagined in the mind of God, hence possessing in Maximus's terms 'logoi,' divinely given patterns of being." Yet, this comes under almost the same critique as the objection to the "only way" argument above. If the "pattern" of a human body is the result of an evolutionary history full of contingency, could the pattern that actually gave rise to humans be imagined? Was the human appendix part of the eternal pattern? If the peak is not so specific that it defines humans as "appendix-bearing", then how can the peak be defined in

\footnotetext{
${ }^{1}$ As a little-discussed side note to this question, if angels exist and are in any sense "creaturely selves" then there must be a way to create creaturely selves apart from evolution. However, there may not be any alternative to evolution to create the sorts of biological creatures that God values. C. S. Lewis's description of humans in The Screwtape Letters as "amphibians - half spirit and half animal... a revolting hybrid" (1944, 45) comes to mind. Perhaps, pure spirits are creatable de novo, but not the hybrid that we are.
} 
such a way that it includes all the members of one species while excluding convergentlysimilar species?

Take large cats as an example. In terms of widely-dispersed creatures of the same species, the commonalities in behavior and "characteristic ways of being" between different species in one ecological setting might be less pronounced than they are with individuals of the same species in a different setting. A Bengal tiger, for example, would have more in common with an Indian leopard in terms of characteristic behavior than it would with a Siberian tiger, even though the Siberian tiger is of the same species. Hunting patterns and food preferences between Bengali tigers and Indian leopards are far more similar to one another than to the hunting patterns and behaviors of the Siberian tiger. Which pattern of being - Siberian or Bengali — did the Logos confer to tigers? Which pattern is most characteristic of the species Panthera tigris? A better example than the same species acting in diverse ways is no doubt the phenomenon of convergent evolution where widely different species crowd themselves onto the same peaks in evolutionary fitness landscapes (McGhee 2008,19-20). Evolutionary peaks, even when dynamic, are not specified enough to distinguish organisms at a species level.

A similar problem emerges when trying simply to define what a species is: Jonathan Jong and Aku Visala, for example, defend a strong species-skeptic view:

The problem is not just one of general vagueness or fuzzy boundaries. Species are not like clouds, with reasonably uncontroversial centers, but vague boundaries. Rather, species are like ever-flowing streams; what we think of as particular species are just slices of the long, uninterrupted phylogenetic history of an evolving population" (2008, 148).

Any possible way to isolate a species boundary diachronically is essentially arbitrary.

The major point I want to make is that using the species demarcation as the pattern of God's creative gift may not be the most useful way to articulate God's work in a creature. A species is simply not a defined enough unit, nor is a peak in the fitness landscape. If I were to 
suggest a change it would be to embrace Southgate's understanding of the Spirit's gift of the particularity of the individual (regardless of species) but to see the gift of the Logos as the whole history of life that informs the particularity of the individual, not the mere species specifications. This has the added advantage of not seeing those born disabled (whether human or non-human) as unable to be "what God intends it to be." Each creature is itself.

Of course, there are difficulties here too. What is an individual? Can an individual human, for example, be distinguished from the bacterial colonies that allow it to flourish? Is a cell in a slime mold to be considered an individual, or is the whole colony one individual? These are not easy questions to solve, and I cannot solve them here. This section may do little more than point out that there is no particularly successful approach when trying to isolate or define divine action, but perhaps that is a helpful warning as well. I hope that it will also add further content to Southgate's excellent ideas about why God did not simply make heaven first. There may simply be no way to produce the outcomes of evolution without the process providing the patterns of selves.

\section{Eschatological Enquiries}

Another area of Southgate's work that has stirred theological comment is his approach to non-human animal eschatology. Drawing heavily on Jay McDaniel's excellent work, Of God and Pelicans, Southgate brings his usual concern for the fate of the individual into eschatological considerations. The usual tactic of brushing aside non-human creatures in eschatology "runs the risk of not doing full justice either to the richness of individual animal experience, or to the theodicy problems that evolutionary creation poses" $(2008,84)$.

By far the most controversial statement Southgate proposes is that there may be preservation, even in predatory animals, of the "characteristics of species, but without pain or death or destruction" $(2008,89)$. In the new creation, according to this view, lions would not 
become straw-eating creatures, but would maintain their hunting relationship with lambs. The new configuration of these relationships, however, would never include fear or pain or the lack of fulfillment present here on earth. The hunt of terror might become "an experience for the redeemed prey-animal that delights in the beauty and flourishing of the predator, and vice versa" (89). For Southgate, the reason for maintaining the possibility of hunting or prey is that these are relationships and behaviors that are essential to the identity of the creatures-to their process of "selving". To strip a lion of tooth and claw, and to leave it without desire to hunt or prowl, is not to have much of a lion. Of course the favor is not all on the side of the lions - the prey might be perfectly fleet, making the hunt an eternal game of tag. Since the exchange would not include terror for the prey nor pains of starvation for the predator, the relationship could be redeemed.

David Clough utterly rejects Southgate's speculations. Clough writes, "Given the visions of harmony between creatures in biblical texts and later Christian traditions surveyed above, it may seem redundant to state the relations between creatures in the new creation will be peaceable... [Southgate's] acceptance of predation as God's original creative intent, continued into the new creation, ontologizes violence" (2012, 158-59). Clough ultimately suggests that the relationship between bird and cat (for example) where the interest shown in the other - now motivated from hunger and fear respectively — could be transformed into one of mutual contemplation or friendliness.

While Southgate foregrounds the importance of skills and behaviors that identify particular ways of being, Clough emphasizes the need for transformation in light of God's peaceable reign. The question comes down to: "Is there a way to reconcile the skills and instincts that make up creatures with the visions of peace?" I want to propose a third possibility: I suggest an analogy to sport (Sollereder 2016). 
Up until recent human history, and still in some parts of the world, people used their ingenuity, their strength, endurance, and technical skills to find ways to hunt and kill other animals. Today, that is fairly rare. The number of people living in my city who have hunted something would be low, and the number of people who relied on hunting to survive would be nil. Yet, people use those same skills that were initially developed for hunting in other ways: in squash and biking and tennis.

In sport, the same skills — the same resources of human identity — are made use of, but without bloodshed. What is more, the skills and abilities in this context often far transcend what would ever have been necessary in the context of hunting. Just watch a few minutes of Olympic gymnasts flying through the air and ask if any hunter (or warrior, for that matter) ever rivaled such feats of physical exertion. The flipping, twisting, gravity-defying bodies whirl through the air with strength, flexibility, and startling precision. Gymnastics is the human body at its most self-transcendent. In a similar way, non-human animals could take up different behaviors but still use their skills and instincts and bodies in ways that no longer come at the cost of other animals. Perhaps they could even integrate these new pursuits in deeper interrelationship with other creatures. Although the mental image of lions and zebras coordinating in synchronized swimming is fairly absurd, Southgate's suggestion of the eternal hunt gains better traction when thought of as sport. Creatures chasing, falling, and rising without terror or pain because the hunt has become play does not ontologize violence.

We have activities in the human realm that preserve the integrity of the skills and instincts of hunting without preserving the bloodshed and violence. It could be possible that identity can be translated without being lost, so that the new kingdom will be peaceable but also full of real and not anemic tigers. 
The second half of this essay attempts to trace how non-traditional theodicies, like Southgate's, can lead to a new direction and use for theodicy as a whole. I have called this new approach "compassionate theodicy".

The subtitle of the Groaning of Creation is "God, evolution, and the problem of evil." It sounds like any number of other books on evolutionary theodicy, whether Michael Murray's Nature Red in Tooth and Claw (2008) or Trent Dougherty's The Problem of Animal Pain (2014). But the approach Southgate takes is radically different from these philosophical accounts. His book is not a typical theodicy that tries to show in a water-tight fashion the multiple reasons a good God might allow or cause suffering in evolution, nor is Southgate trying to defend God against the claims of skeptics who point to evil as the evidential proof that God does not exist. He writes: "I am working within the community of belief to face the problems and tensions that come as we try to understand the God who made this world and who, Christians believe, acts to save it" $(2008,6)$. Southgate proposes an "adventure in the theology of creation" that "arise[s] out of protest and end[s] in mystery" (16).

Can an exploration of God's nature in this way be called a "theodicy"? Not according to Murray, who defines theodicy as the "aim to provide the known truth about why God permits evil" $(2008,37)$ or in Peter van Inwagen's words, "a story that is told as the real truth of the matter" $(2006,7)$. Southgate's approach is far more tentative, far more speculative than asserting "the known truths." It starts from a different concern.

In A Grief Observed, C.S. Lewis writes, after the death of his wife, "[It is] not that I am (I think) in much danger of ceasing to believe in God. The real danger is of coming to believe such dreadful things about Him. The conclusion I dread is not 'So there's no God after all,' but 'So this is what God's really like. Deceive yourself no longer'” (1961, 6-7). The project Southgate pursues is a response to this sort of question, not the question of the atheist or agnostic skeptic toward whom most theodicies are turned. An adventure in theology leads 
down highly speculative and unproveable paths. Yet its intention is to sketch a picture of God that is faithful to both the Christian tradition and scientific understandings about the world.

A common response to theodicy is the complaint of the "anti-theodicists" that theodicies are immoral and unhelpful. John Swinton and D. Z. Philips, amongst others, charge that theodicies contribute to the evil of experience rather than offer any aid to those who suffer (Swinton 2007; Phillips 2004). And this is true of many pieces of theodicy that boldly and without sensitivity claim to know the outweighing goods in light of horrors such as rape, genocide, or especially, the Holocaust. D. Z. Philips rightly protests:

I say that 'no one in their right mind' would speak in this way, while knowing that many philosophical religious apologists do. But my language registers my amazement at the fact. I have found the same amazement among non-philosophically minded people, believers and non-believers alike...the most common response is 'God God! They don't say that do they?' (Phillips 2004, 70)

More recently, philosophers have taken note of the concerns of anti-theodicists.

Eleonore Stump's Wandering in Darkness includes the statement:

Although it is vitally important for us to remember the Holocaust and to reflect deeply on it, taking it simply as one more example or counterexample in academic disputation on the problem of evil strikes me as unspeakably awful. It is enough for me that I am a member of the species that propagated this evil. Stricken awe in the face of it seems to me to be the only response bearable. $(2010,16)$

Is the charge of radical insensitivity one that could be leveled against Southgate's work? I do not think so, for two reasons.

The first reason is that in order to be able to respond effectively to evil (the goal of the anti-theodicists), we must understand what constitutes evil. Some readers might think that evil is obvious, and in many cases that is true. When we see war, genocide, hatred, rape: there is no question about both the evil of the situation and the responsibility we bear to respond and resist. But in other cases, the right path is not so clear-especially when we consider disvalues in nature. Should we consider predatory instincts as a result of evil? If we do, does it become part of the human mandate to train lions and wolves not to hunt? Are all disease 
and sickness evil, and if so, what responsibility do humans have for medicating wild populations? Southgate's approach, which embraces creation as "the good and the groaning," acknowledges that disvalues are not always simply a problem to be solved. The devastation caused by the opioid crisis in the States, for example, stands as a stark warning that the best technological advances combined with the best intentions cannot relieve the paradox that life on this earth is composed of the "good and the groaning".

The second reason that I don't think Southgate's approach is open to the antitheodicist critique is that the narrative within which suffering happens matters. The way in which we think about our suffering — that is, the sort of thing an "adventure in theology" might try to sort out — can have dramatic effects on perceived levels of suffering. Pain studies performed at the Nuffield Department of Anaesthetics (Weich, et al. 2009) found that people with strong religious belief were able to modulate their experience of pain while contemplating a religious image (in this case, an image of the Virgin Mary) but could not do so when contemplating a control image (Leonardo da Vinci's "Lady in Ermine"). The study suggested that the analgesic effect was due to a known pain-regulatory mechanism known as "reappraisal". According to the study, "reappraisal is a process of reinterpreting the meaning of a stimulus leading to a change in one's emotional response to it" (Weich, 474, Cf. Gross, 2002). In short, if we think differently about our situation, the emotional responses associated with suffering can be diminished. Reappraisal should be contrasted with suppression, which inhibits the outer expression of feelings late in the process rather than refocusing the inner feelings early in the generation of emotion. (Gross, 2002)

Reappraisal is foundational to the practice of Cognitive Behavioral Therapy (CBT). CBT trains people to step back from the immediacy of emotional situations, think through their cognitive reactions and adjust them in order to change the emotional outcomes of situations. That suffering should be context-dependent is intuitive. It makes sense that a 
woman giving childbirth suffers differently from the person being senselessly tortured by enemies. The same is true of fear: even a very small pain can become unbearable if it is associated with overwhelming fear. People who are afraid of needles and those who are not experience the same small pinch physically, but the emotional effect this has, and the level of suffering experienced by the two groups, is widely different. Yet, by retraining the mind to respond differently to the painful stimulation, the suffering involved can be decreased.

Since the context of suffering affects the perceived level of suffering, then using theology as part of the toolkit for people to reappraise their situations would help rather than harm them, if done with sensitivity, appropriate timing, and offered as tentative pieces of meaning-making rather than as a done-and-dusted solution. I suggest that in so far as theodicy is a meaning-making endeavor, it could potentially offer aid to Christian believers in reappraisal activities. I am calling this approach 'compassionate theodicy'.

Compassionate theodicy could draw on the resources of religious belief and the sciences to provide alternative frameworks of meaning that allow people to reinterpret their situation in ways that diminish emotional isolation and distress, and thus lower the overall perception of suffering. Weich's work (2009) shows that religious belief can play an important analgesic role through reappraisal strategies in straightforward physical pain, but since reappraisal also works in complex social and emotional situations, there is no reason to think that reappraisal through religious belief would not be more widely applicable in human experience. An example of where this sort of compassionate approach is used is in 1

Thessalonians 3:13-18 (NRSV), where Paul instructs the brothers and sisters in the church of Thessalonica on how to interpret the meaning of death:

Brothers and sisters, we do not want you to be uninformed about those who sleep in death, so that you do not grieve like the rest of mankind, who have no hope. ${ }^{14}$ For we believe that Jesus died and rose again, and so we believe that God will bring with Jesus those who have fallen asleep in him... ${ }^{16}$ For the Lord himself will come down from heaven, with a loud command, with the voice of the archangel and with the trumpet call of God, and the dead in Christ will rise first. ${ }^{17}$ After that, we who are still 
alive and are left will be caught up together with them in the clouds to meet the Lord in the air. And so we will be with the Lord forever. ${ }^{18}$ Therefore encourage one another with these words.

The approach of the apostle to the grief experienced by the church members is not to deny them the chance to grieve, but to contextualize their grief in a way that allows them to reappraise how they encounter death.

If theodicy can be transformed into a compassionate endeavor, theodicy would have to undergo at least two major changes: audience and methodology. In terms of audience, the intention would shift from an outward-focused attempt to disarm the theoretical arguments against the existence of God to an inward-focused (within the community of Christians) attempt to "encourage one another with these words."

In terms of methodology, a compassionate theodicy would have to be willing to engage with affect and refuse to see horrendous evils merely as abstract data points in debate. If the readers of a compassionate theodicy are assumed to be people who are going through suffering (instead of being dispassionate philosophers), then they do not need external examples of suffering to "illustrate" the presence of evil in the world. They know it exists already through their own experience. Providing the intellectual resources necessary to reframe a situation of suffering becomes the priority: there is no need to 'set up the argument.' A compassionate theodicy would also embrace narrative, and refuse to accept that all that is important about a story or situation can be extracted and represented in abstract propositional form (Stump 2010). Likewise, compassionate theodicy would embrace practical responses, and include practical aid, lament, and the other elements of resistance and transformation proposed in John Swinton's pastoral theodicy (2007). Finally, the primary aim would be to provide the intellectual resources necessary to aid people in the process of meaning-making. In this case, the approach is more tentative than the bold claims of philosophical theodicists who claim that they know the reasons for God's allowing the 
existence of evil. Nor would it create a defence (à la Plantinga) that portrays merely plausible reasons for the existence of evil. Instead, a compassionate theodicy would draw on the resources of theology and science to provide elements of a meaningful framework that the suffering person can use to assemble meaning in their own circumstances.

The approach of compassionate theodicy provides intellectual resources, not finished answers. It leaves the assembly and use of the intellectual resources up to the individual. An analogy is the business model of companies like Blue Apron or Abel \& Cole that have responded to the complexities of the modern family with an innovative approach to meal preparation. People want to make homemade meals and not buy ready-cooked or microwave dinners. Yet, they don't have the time and resources to plan, measure, and cook meals. So, Blue Apron will deliver all the ingredients for a meal in all the right quantities, ready to be combined and cooked. Then, the cook can tailor the meal to their own taste: add or remove spices and sauce, tinker with the ingredients, or change the portion size. The person gets the advantages of a home-cooked meal, but without using all the time resources that would traditionally go into getting these advantages. In a similar way, a compassionate theodicy might provide elements of Christology, eschatology, science, and lament that can remind or recontextualize the experience of the individual so that they can reappraise their situation, but would not provide "answers".

A new area in Christopher Southgate's work, not yet widely known, is path-finding in this new type of theodical endeavor. Southgate is the head investigator on a project at the University of Exeter called "Tragedy and Congregations" that recognizes "congregational flourishing can be jeopardized when tragic events threaten ordinary frames of meaning within which groups of worshippers live" (https://tragedyandcongregations.org.uk/project/). By integrating psychological knowledge of trauma with liturgical and theological resources, ordinands are encouraged to develop resources that form wisdom in the integration of the 
narrative of Christian Scripture and practices of prayer. The natural sciences can offer helpful tools for theological reappraisal. For example, in the case of natural disasters such as earthquakes, the geological knowledge that plate tectonics are essential to a life-bearing planet can reduce the sense that a natural disaster is the result of divine punishment or caprice. Knowledge of this sort can help develop personal theodicies that serve as anchors for spiritual care providers in traumatic situations (Schruba 2017, 43). These personal theodicies can then be discussed in time and context-sensitive ways with those who are traumatized. It is time for theodicy to move beyond the intellectual sparring match it has become between theist and atheist philosophers, and for it to become a resource for the church, building the imagination of the possibilities of divine presence and compassion. Southgate, as usual, is found ahead of the curve in developing new paths in theology.

Bibliography

Clough, David. On Animals: Volume 1. Systematic Theology. 2012. London, Bloomsbury. Darwin, Charles. Letter to Asa Gray, 11 December 1861. Darwin Correspondence Project, "Letter no. 3342," accessed on 4 February 2018, http://www.darwinproject.ac.uk/DCP-LETT-3342

Dougherty, Trent. The Problem of Animal Pain: A Theodicy for All Creatures Great and Small. 2014. Basingstoke: Palgrave.

Gross, James J. 2002. "Emotion regulation: affective, cognitive, and social consequences." Psychophysiology 39: 281-91.

Jong, Jonathan and Aku Visala. 2014. "Three Quests for Human Nature: Some Philosophical Reflections." Philosophy, Theology and the Sciences 2:146-171.

Lewis, Clive S. A Grief Observed. 1961. New York, HarperCollins. . The Screwtape Letters, 1944. London: Geoffrey Bles.

McGhee, George. 2008. "Convergent Evolution: A Periodic Table of Life?” in The Deep Structure of Biology, ed. Simon Conway Morris, 17-31. West Conshohocken, PA: Templeton Foundation Press.

Murray, Michael. 2008. Nature Red in Tooth and Claw. Oxford: Oxford University Press.

Schruba, Alice N. "Practical Presence: A Grounded Theory of Disaster Spiritual and Emotional Care in Practice." 2017. Dissertation: Wheaton College.

Sollereder, Bethany. 2016. "When Humans are Not Unique: Perspectives on Suffering and Redemption." The Expository Times, 269-276.

Southgate, Christopher. 2008. The Groaning of Creation: God, Evolution and the Problem of Evil. Louisville: Westminster John Knox. 
Stump, Eleonore. 2010. Wandering in Darkness: Narrative and the Problem of Suffering. Oxford: Clarendon.

Swinton, John. 2007. Raging with Compassion: Pastoral Responses to the Problem of Evil. Grand Rapids, MI: Eerdmans.

Van Inwagen, Peter. 2016. The Problem of Evil. Oxford: Clarendon.

Weich, Katja, Miguel Farias, Guy Kahane, Nicholas Shackel, Wiebke Tiede, and Irene Tracey. 2009. "An fMRI study measuring analgesia enhanced by religion as a belief system." Pain 139: 467-476.

Wahlberg, Mats. 2015. "Was evolution the only possible way for God to make autonomous creatures? Examination of an argument in evolutionary theodicy." Int J Philos Relig. 77: $37-51$. 